\title{
ARRENDAR EL DINERO DEL REY. FRAUDE Y ESTRATEGIAS FINANCIERAS EN EL ESTRADO DE LAS RENTAS EN LA CASTILLA DEL SIGLO XV ${ }^{1}$
}

\author{
FARMING THE ROYAL REVENUES. \\ FRAUD AND FINANCIAL STRATEGIES: \\ THE «ESTRADO DE LAS RENTAS»IN 15th CENTURY CASTILE
}

\section{ÁGATA OrTega CERA \\ Université de Lyon 2/UMR 5648-CIHAM}

Resumen: El presente artículo profundiza en el arrendamiento de rentas regias de la Castilla de la segunda mitad del siglo XV, desde la óptica del negocio fiscal. El complejo proceso administrativo que suponen los arrendamientos de rentas no puede entenderse, únicamente, como un medio de percepción fiscal, sino que hay que conectarlo con otro tipo de campos de actuación política y económica relacionados con el negocio fiscal y financiero. Este trabajo analiza algunos de los mecanismos desarrollados en las subastas de las rentas, que permitían a los hombres de negocios convertirse en arrendadores de determinados tributos.

Palabras clave: Reyes Católicos; Castilla; Siglo XV; Fiscalidad regia; Arrendamientos.

\begin{abstract}
This article explores the royal income from leasing of Castile in the second half of the fifteenth century, from the standpoint of the business tax. The complex administrative process involving the hiring of income can not be understood solely as a mechanism of tax collection, but must be related to other fields of economic and political action related to fiscal and financial business. This paper mainly emphasizes on analyzing some of the mechanisms developed in the auctions of the income that allowed business people to become landlords of certain tributes.

Key words: Catholic Kings; Castile; 15th century; Royal taxation; Landlords; Leasing.
\end{abstract}

1. Introducción.- 2. El Estrado de las Rentas.- 3. El fraude en las subastas de las rentas según la legislación hacendística.- 4. De la legislación a la "calle": algunos ejemplos.- 5. La connivencia de la Corona.- 6 . A modo de conclusión.

${ }^{1}$ Este artículo se inscribe en el marco del proyecto de investigación "El Reino de Granada y la Corona de Castilla: Hacienda y, Fiscalidad (1485-1570)" (Ref. HUM 2007-60331), integrado 


\section{INTRODUCCIÓN}

Porque no pienso parar hasta verte arrendador o alcabalero, que son oficios que aunque lleva el diablo a quien mal los usa, en fin en fin, siempre tienen y manejan dinero ${ }^{2}$.

Corría el año 1487 cuando un nutrido grupo de financieros - conformado en su mayoría por judíos y judeoconversos- intentaron derrotar a la poderosísima compañía liderada por Rabí Mayr, Abraham Seneor y Luís de Alcalá3.

Unos años más tarde, la recién inaugurada sociedad de Fernando de Villarreal y su cuñado Alonso Gutiérrez de Madrid, lograba poner en serios aprietos a la principal compañía castellana hasta conseguir relegarla allá por el año 1494: era el inicio de la época dorada de la naciente y flamante compañía ${ }^{4}$.

1497; Alonso de Alanís se convertía en el repartidor general de la renta de la seda del Reino de Granada, pasando a controlar una parte importantísima de esta renta, y desplazando a los hermanos Abduladín a arrendamientos menores 5 .

1517-1519; El sevillano Pedro del Alcazar conseguía hacerse casi con la totalidad de los arrendamientos de la Andalucía occidental y del Reino de Granada ${ }^{6}$.

Las páginas que siguen a continuación forman parte de la senda que han marcado algunos estudios recientes, que se integran en la corriente

\footnotetext{
${ }^{2}$ Miguel DE CERVANTES, Don Quijote de la Mancha. Introducción y notas de Martín de Riquer, Barcelona, 2004, p. 538 (Carta de Teresa Panza a Sancho Panza, su marido).

${ }^{3}$ Sobre este episodio vid. Carlos Álvarez García, Los judios y la hacienda Real bajo el reinado de los Reyes Católicos. Una compañía de arrendadores de rentas Reales, "Las tres culturas en la Corona de Castilla y los sefardíes", 1990, pp. 99-100; Miguel Angel LADERO QUESADA, La receptoría y pagaduría general de la Hacienda regia castellana entre 1491 y 1494 De Rabí Meír Melamed a Fernán Núnez Coronel), "En la España Medieval", 25 (2002), pp. 427 431: María del Pilar RÁBADE OBRADÓ, La élite judeoconversa de la Corte de los Reves Católicos y el negocio fiscal, en Fiscalidad y Sociedad en el Mediterráneo bajomedieval (A. GALÁN SÁNCHEZ, ed.), Granada, (En prensa) (Agradecemos a la autora que nos permitiese utilizar el trabajo aún inédito).

${ }^{4}$ Algunos datos sobre esta compañía en: Luis Rafael VILLEGAS DíAZ, Sobre judeoconversos manchegos. Unas apreciaciones, "Encuentros en Sefarad", Ciudad Real, 1987, pp. 182-187; C. AlVAREZ GARCí, Los judios y la hacienda Real, op. cit. pp. 105-111; María Angeles MARTín ROMERA, La imposicion de los criterios económicos urbanos al entorno rural: el caso de los mercaderes de Almagro, "La Ciudad medieval y su influencia territorial. Nájera Encuentros Internacionales del medievo" Logroño, 2006, pp. 205-220; Agata ORTEGA CERA, La Fiscalidad Regia en el Obispado de Granada tras la conquista castellana (1491-1502), Málaga, 2009 [Tesis Doctoral Inédita, Universidad de Málaga], donde desarrollamos los años de mayor esplendor de esta compañía.

${ }^{5}$ A. ORTEGA CERA, Arrendadores y recaudadores en el Obispado de Granada bajo el reinado de los Reyes Católicos. Una aproximación a las compañías financieras, en Fiscalidad y Sociedad en el Mediterráneo bajomedieval (A. GALÁN SÁNCHEZ, ed.), Granada,, (En prensa).

${ }^{6}$ Juan Manuel CARRETERO ZAMORA, Los arrendadores de la Hacienda de Castilla a comienzos del s. XVI (1517-1525), "Studia Histórica", 21 (1999), pp. 154-163.
} 
renovadora de la new fiscal history o nueva historia fiscal ${ }^{7}$. Una historia que poco o nada tiene que ver con el clásico estudio de los tradicionales aspectos institucionales y de las relaciones de ingresos y gastos, pues la actual historiografía dirige parte de sus esfuerzos en superar el marco institucional, dejando atrás el análisis exclusivo de los órganos centrales, para ocuparse de una historia fiscal centrada sobre todo lo relacionado con el ejercicio del poder o las consecuencias sociales de la fiscalidad.

Esta tendencia a abordar elementos como los mecanismos de negociación entre los diversos poderes, el estudio de la gestión y percepción de los impuestos, el papel desempeñado por las elites financieras o emprender el estudio de la fiscalidad desde el gasto, desde el crédito, desde el fraude o la corrupción, son nuevos campos de estudio que permiten abordar los sistemas fiscales desde novedosas perspectivas ${ }^{8}$. La Nueva Historia Fiscal coloca al poder financiero como sujeto de análisis en los regímenes fiscales históricos, e integra a la fiscalidad dentro de una visión multiforme junto a consideraciones políticas y sociales ${ }^{9}$.

Enmarcada dentro de esta Nueva Historia Fiscal, encontramos la que podríamos denominar Vertiente Sociológica de la Fiscalidad, una de las líneas de trabajo más novedosas y preferentes en la actualidad, que permite establecer conexiones entre los poderes políticos, sociales y financieros. Sólo en los últimos años parece haber trascendido la importancia del estudio de los llamados intermediarios fiscales o agentes del fisco, como elemento fundamental para poder llegar a entender y conocer la organización y actividad hacendística de cualquier régimen fiscal, pues la labor que desempeñan como intermediarios entre la Hacienda y los contribuyentes

\footnotetext{
${ }^{7}$ Un buen exponente de cuales son los caminos de la reciente historia fiscal, lo proporciona la compilación preparada por Richard BONNEY sobre el desarrollo de las estructuras hacendísticas en diversos países europeos: desde la baja edad media hasta fines del s. XVIII. Sistémes economiques et finances publiques, París, 1996 o J.D. TRACY, Taxation and state debt en Handbook of European History. Late Middle Ages, Renaissance and Reformation, I, ( T.A. OBERMAN; J.D. TRACY, eds.). Leiden-Nueva York-Colonia, 1994, pp. 563-588.

${ }^{8} \mathrm{Sin}$ pretender ser exhaustivos -pues es muy abundante la producción historiográficadestacaremos algunos de los trabajos más significativos. Algunas síntesis de gran utilidad: M.A. LADERO QUESADA, Estado. Hacienda. Fiscalidad y Finanzas. El medievalismo español en los últimos treinta años. 1968-1998, "XXV Semana de Estudios Medievales de Estella", Pamplona, 1999, pp. 457-504; Benito HERNÁNDEZ, Finanzas y Hacienda en los territorios de la monarquía hispánica. Revista de una década historiográfica, 1988-1998, "Cuadernos de Historia moderna" 21, (1990), pp. 267-326; David ALONSO GARCíA, Poder y finanzas en Castilla en el tránsito a la modernidad (un apunte historiográfico), "Hispania, Revista Española de Historia", LXVI-222, (2006), pp. 157-198; Florent GARNIER, Fiscalité et finance médiévales: un état de la recherche, "Revue historique de droit français et étranger", 3, (2008), pp. 443-452. En lo que respecta a Occidente Mediterráneo tenemos que destacar los trabajos que desde hace más de una década realiza el equipo hispano-francés liderado por Denis MENJOT y Manuel SÁNCHEZ MARTÍNEZ, La fiscalité des villes au Moyen Age (France meridionale, catalogne et Castille). 1. Etude de Sources, Toulouse, 1996; 2. Les systémes fiscaux, Toulouse, 1999; 3. La redistribution de l'impôt, Toulouse, 2002; 4 . La gestión de l Impôt, Toulouse, 2004; L'impôt dans las villes de l'Occident méditerranéen XIII-XV siécle, París, 2005; Fiscalidad de Estado y fiscalidad Municipal en los Reinos Hispánicos Medievales, Madrid, 2006. También debemos referir los estudios que sobre deuda pública en Cataluña llevan desarrollándose años. Una muestra representativa puede verse en una recentísima publicación, M. SÁNCHEZ MARTínEZ (ed.), La deuda pública en la Cataluña bajomedieval, Barcelona, 2009 o en otros lugares de la monarquía hispanica, B. HERNÁNDEZ, Fiscalidad de reinos y deuda pública en la monarquía hispánica en el siglo XVI, Córdoba, 2002.

${ }^{9}$ D. Alonso GARCíA, El Erario del Reino. Fiscalidad en Castilla a principios de la Edad Moderna, Valladolid, 2007, pp. 9-19.
} 
condiciona la situación económica y política de los reinos: el sistema fiscal necesita de los financieros a la hora de efectuar el cobro de las rentas ${ }^{10}$.

A través de estas líneas pretendemos adentrarnos en el fenómeno del negocio fiscal desde una óptica muy concreta, que esperamos contribuya a esclarecer un sistema de recaudación, tan confuso y tan complejo, como era el sistema de arrendamientos ${ }^{11}$.

Aunque el negocio fiscal y financiero no está asociado ni circunscrito a un sistema fiscal concreto ni a un mecanismo de recaudación, en la Castilla de finales del siglo XV — fecha y lugar en los que desarrollamos nuestra investigación - era el arrendamiento de rentas la práctica más extendida, más consolidada y más utilizada a lo largo y ancho de la Corona castellana. El próspero reinado de los Reyes Católicos, la incorporación del Reino de Granada tras su conquista ${ }^{12}$, las transformaciones hacendísticas llevadas a cabo $^{13}$, la estabilización monetaria ${ }^{14}$ o la puesta en marcha de un nuevo

${ }^{10}$ Por citar solamente algunos de los trabajos que se han venido realizado últimamente en esta línea: Jean Claude WAQUET e Denis MENJOT (coord.), Transazioni, strategie e racionalità fiscali nell'Europa medievale e moderna, "Cheiron. Materiali e instrumenti di aggiornamento storiografico", 24 (1995); M. BOONE, Stratégies fiscales et financiéres des élites urbaines dans les anciens Pays bas face á l'Etat burgundo-habsbourgeois, en L'Argent Au Moyen Age, Paris, 1998, pp. 235-253; Bernardo José LOPEZ BELINCHÓN, Honra, libertad y hacienda (hombres de negocios y judios sefardíes). Alcalá de Henares, 2001; J.M. CARRETERO ZAMORA y D. ALONSO GARCÍA, Hacienda y negocio financiero en tiempos de Isabel la Católica. El libro de Hacienda de 1503, Madrid, 2003; D. MENJOT y M. SÁNCHEZ (coords.), La fiscalité des villes au Moyen Age 4 : La gestion de l'impôt, op. cit; Amalia GARCÍA PEDRAZA, La prosopografía de los intermediarios fiscales del Reino de Granada (1492-1515). Una historia por hacer "Crónica Nova", 31, (2005), pp. 147-195; F. GARNIER, Un consulat et ses finances: Millau (1187-1461), París, 2006; D. ALONSO, El Erario del Reino, op. cit; J. M. CARRETERO ZAMORA, La Averiguación de la Corona de Castilla 1525-1540. Los buenos vecinos pecheros y el dinero en época del emperador Carlos V, Salamanca, 2008; Isabel AGUIRRE LANDA, Para una sociología de los arrendadores de la corona de Castilla: la información de abonos, en Fiscalidad y Sociedad en el Mediterráneo bajomedieval, op. cit. (Agradecemos a la autora que nos permitiese utilizar el trabajo aún inédito). (Hemos obviado aquellos trabajos que analizan la trayectoria de un personaje o de una familia por ser una producción demasiado abundante).

${ }^{11}$ Un sistema que a pesar de haber sido solidamente estudiado -sobre todo a partir de dos obras fundamentales- M.A. LADERO QUESADA, La Hacienda Real de Castilla en el siglo XV. La Laguna, 1973 y Miguel Angel Solinís ESTALló, La Alcabala del Rey (1474-1504). Fiscalidad en el partido de las Cuatro Villas cántabras y las merindades de Campoo y Campos con Palencia, Cantabria, 2003, hay cuestiones que la historiografía aún no ha terminado de resolver. Lo pusimos de manifiesto en nuestra tesis doctoral e intentamos contribuir al esclarecimiento de algunas de ellas. A. ORTEGA, La Fiscalidad Regia en el Obispado de Granada, op. cit.

${ }^{12}$ Rafael Gerardo PEINAdo SANTAELla (ed.), Historia del Reino de Granada. De los orígenes a la época mudéjar (hasta 1502), I, Granada, 2000. Para todo lo relacionado con el sistema fiscal y los nuevos ingresos que la Corona comenzaría a disfrutar: M.A. LADERO QUESADA, Rentas de Granada, en Granada después de la conquista. Repobladores y mudéjares, Granada, 1988, pp. 261-271; Angẹl GALÁN SÁNCHEZ, Los mudéjares del Reino de Granada, Granada, 1991, pp. 105 129; José Enrique LÓPEZ DE COCA CASTANER, La fiscalidad mudéiar en el Reino de Granada "Actas del V Simposio internacional de Mudejarismo" Teruel, 1991, pp. 191-219; A. ORTEGA, La Fiscalidad Regia en el Obispado de Granada, op. cit.

${ }^{13}$ Se fortaleció el régimen de Contadurías, se abordó el problema de los excesivos juros, se reformaron algunas de las normativas de recaudación de los impuestos, y se creó una receptoría pagaduría para todo el Reino. M.A. LADERO QUESADA, La Hacienda Real de Castilla, op. cit; Estado. Hacienda, Fiscalidad, op. cit.

${ }^{14}$ José María DE FRANCISCO OLMOS, La evolución de los cambios monetarios en el reinado de Isabel la Católica según las cuentas del tesorero Gonzalo de Baeza (1477-1504), "En la España medieval” 21, (1998), pp. 115-142. Javier DE SANTIAGO FERNÁNDEZ, Política monetaria en Castilla durante el siglo XVII, Valladolid, 2000, pp. 21-32. 
sistema de recaudación ${ }^{15}$, son elementos suficientes para entender por qué en las últimas décadas del siglo XV, asistimos a un extraordinario desarrollo del fenómeno fiscal.

Si bien muchos de los aspectos que vamos a desarrollar en el presente trabajo podrían ser perfectamente extrapolables a otras zonas de la monarquía hispánica, a otros sistemas fiscales ${ }^{16}$, e incluso nos atrevemos a decir a otros mecanismos de recaudación ${ }^{17}$, nuestro trabajo va a centrarse en un aspecto esencial de la Hacienda castellana: el negocio del arrendamiento de las rentas regias, analizado desde un observatorio privilegiado: el Estrado de las Rentas.

\section{EL ESTRADO DE LAS RENTAS}

Nos vos mandamos que todos e cualesquier partidos de nuestras rentas de alcabalas e terçias e pechos e derechos (...) que las arrendedes e pongades en almoneda publica en el estrado de las nuestras rentas (...) e que podades dar e otorgar en ellas los prometidos que a vosotros bien visto vos fuere, e hazed los arrendamientos y remates dellas con las condiçiones de los nuestros quadernos ${ }^{18}$.

Tal y como hemos mencionado anteriormente, el sistema de recaudación por excelencia en Castilla durante el siglo XV era el sistema de arrendamiento $^{19}$; procedimiento mediante el cual casi todas las rentas pertenecientes a la monarquía se arrendaban a personas o a grupos que pagaban a la Corona un precio determinado por ellas, y que corrían tanto con las ventajas como con las desventajas de su cobro ${ }^{20}$.

\footnotetext{
${ }^{15} \mathrm{El}$ encabezamiento ha sido tan estudiado en la Corona castellana, que sería imposible reflejar todos los títulos aquí. Por su carácter general destacamos los trabajos de: Manuel VILLEGAS RUIZ, Córdoba, 1995. María ASENJO GONZÁLEZ, Los encabezamientos de alcabalas en la Castilla bajomedieval, en Fiscalidad de Estado y fiscalidad municipal op. cit. pp. 135-170.

${ }^{16}$ Como por ejemplo la fiscalidad concejil. Antonio COLLANTES DE TERÁN, Los fiadores en la hacienda concejil sevillana bajomedieval, "Mayurqa" 22.1, (1989), pp. 191-197; Arrendatarios de rentas públicas en Carmona, "Archivo Hispalense" LXXX, (1998), pp. 327-347.

${ }^{17}$ Realmente la diferencia entre encabezamiento y arrendamiento no es tan distinta si observamos ambos mecanismos bajo el prisma del negocio, algo que ya señalaron en su día: D. ALONSO GARCÍA, Carlos V, Madrid y la hacienda real de Castilla, "Revista de historia económica" 21.2, (2003), pp. 271-295; Una Corte en Construcción. Madrid en la Hacienda Rea de Castilla (15i7-1556), Madrid, 2005; A. GALÁN SÁNCHEZ Rentas ordinarias y encabezamientos en el Reino de Granada (1499-1517): la construcción de un sistema de fiscalidad de Estado. (inédito).

${ }^{18}$ M.A. LADERO QUESADA, Legislación hacendística de la Corona de Castilla en la Baja edad media, Madrid, 1999, p. 83. La cursiva es nuestra.

${ }^{19} \mathrm{El}$ sistema de arrendamiento empezó a extenderse en Castilla a partir del siglo XIV, aunque mucho antes ya se utilizaba el arrendamiento como mecanismo de extraccion, apareciendo recogido en las partidas de Alfonso X: M.A. LADERO QUESADA, Fiscalidad y poder Real en Castilla (1252-1369), Madrid, 1993, pp. 255-257.

20 "Que los arrendadores que arrendaren las dichas alcabalas las cojan e recabden a toda su aventura poco o mucho lo que oviere" M.A. LADERO, Legislación hacendística, op. cit. p. 120.
} 
El arrendamiento de rentas tenía como última finalidad generar beneficios a las dos partes implicadas en la relación contractual ${ }^{21}$. Por un lado, la Corona conseguía que un intermediario se encargase de la fatigosa tarea de recaudar sus tributos y de cubrir con ese dinero las principales necesidades (pagos de situados, libranzas y prometidos) ${ }^{22}$, y por otro el arrendador pretendía obtener todos los privilegios que conllevaba ser arrendadorrecaudador mayor de los monarcas ${ }^{23}$. En primer lugar, un beneficio estrictamente económico generado de los incentivos y ganancias obtenidos en los procesos de subasta y de subarrendamiento ${ }^{24}$. En segundo lugar, arrendar ciertas rentas suponía también colocar en posiciones muy ventajosas la producción y el tráfico de determinados productos, que en muchas ocasiones ayudaban al arrendador a fortalecer sus propios negocios ${ }^{25}$ y en tercer lugar, la gestión de los impuestos era un medio de vinculación al poder, que acababa transformándose en un medio de promoción social ${ }^{26}$.

21 "Consyderamos que una de las principales leyes que syenpre han seydo puestas en cuadernos de alcabalas de grandes tienpos acá es que el arrendador arriende la renta a toda su ventura, poco o mucho, reçebiendo en sy los peligros de todos los casos fortuytos, e sy se dixiese que los arrendadores arriendan a su peligro para perder e no reçebian el aventura de su ganançia parecería ser ley ynteresal e no contrabto de buena fee", Ibíd. p. 207. La cursiva es nuestra.

${ }^{22}$ Puesto que el arrendador-recaudador mayor se encargaba de todo el proceso: desde subarrendar las rentas hasta realizar los pagos encargados por la Corona.

${ }^{23}$ Todos los arrendadores -y no solamente el arrendador-recaudador mayor- gozaban de ciertos privilegios y obtenían una serie de ganancias. Sin embargo era éste, figura que se sistematiza a partir del siglo XV, el que obtendrá mayores beneficios al supervisar el proceso completo de arrendamiento.

${ }^{24}$ Debido a la dificultad que entraña su análisis han sido procedimientos muy poco estudiados, por lo que seguimos desconociendo lo esencial de ellos. En lo que respecta a los prometidos y cuartas partes de pujas, los trabajos que han abordado dichos incentivos se han centrado en ofrecer una descripción detallada del momento de la subasta en el que podían obtenerse, pero seguimos sin conocer cual es la relación existente entre los prometidos y las cuantías de las rentas a arrendar. M.A. Solinís, La Alcabala del Rey (1474-1504), op. cit. pp. 116-124; A. COLLANTES DE TERÁN SÁNCHEZ, El sistema de arriendo de las rentas concejiles en las ciudades andaluzas en la baja edad media, en La Fiscalité des villes au Moyen Â (Occident méditerranéen). 4. La gestion, op. cit. pp. 205-209; Adelina ROMERO MARTÍNEZ,La intervención de los agentes del fisco castellano: de la Corona a los concejos en La Fiscalité des villes au Moyen Age (Occident méditerranéen). 4. La gestion, op. cit. pp. 74-76. Mucho más parcos son los trabajos en los que se presta atención a los arrendamientos al por menor, y mucho menos aquellos que han logrado medir el margen de ganancia que obtenía el arrendador entre el arrendamiento al por mayor y el arrendamiento al por menor. Remitimos a nuestra tesis doctoral donde pudimos hacerlo para algunas rentas del Obispado granadino A. ORTEGA, La Fiscalidad Regia en el Obispado de Granada, op. cit.

${ }^{25}$ Los límites entre comerciantes y arrendadores eran fluidos y porosos, siendo muchos los casos en los que ambas actividades se aunaban en una misma persona, familia o compañía. Linda MARTZ, Los toledanos y el Reino de Granada, de 1492 a la década de 1560, en España, Europa y el mundo Atlántico, "Homenaje a John. H. Elliot" (R.L. KAGAN; G. PARKER eds.), 2002, pp. 151-176; D. ALONSO, Poder financiero y arrendadores de rentas reales en Castilla a principios de la Edad Moderna, "Cuadernos de Historia Moderna", 31 (2006), pp. 117-138.

${ }^{26}$ Fueron muchos los personajes que comenzaron en el negocio de las rentas y acabaron formando parte de lo más granado de la sociedad castellana entroncándose con la nobleza señorial u ocupando oficios que los integraban de lleno en la oligarquía. Marcos de Madrid, la familia Pissa, el propio Alonso Gutiérrez de Madrid y otros muchos tesoreros del rey y Contadores mayores son una buena muestra de ello. Vicente PARELLO, Un oligarca converso de la Mancha en el siglo XVI: el caso de Marcos de Madrid, "Sefarad", 58/2, (1998), pp. 315-337; Andrés VAZQUEZ CANO, Los pissas "Revista del Centro de Estudios Históricos de Granada y su Reino", IV, (1914), pp. 157-170; José MARTíneZ MILlÁN, Carlos Javier DE CARLOS MORALES, 'Los conversos y la Hacienda Real de Castilla en la primera mitad del siglo XVI: las actividades de Alonso Gutiérrez de Madrid en la Corte de Carlos V. Siglos dorados: homenaje a Agustín REDONDO, P. CIVIL (coord.), 2, 2004, pp. 915-931; D. ALONSO, El Erario del Reino. op. cit. pp. 143-200. La trayectoria de algunos de estos personajes (haciendo especial hincapié 
El sistema de arrendamientos se convirtió en un auténtico filón, no solamente para los arrendadores sino también para todo el elenco de personajes que de forma directa o indirecta participaban en él: arriesgando su capital a cambio de obtener sustanciosos beneficios. Las subastas de rentas componían un proceso administrativo muy complejo que se desarrollaba a lo largo de numerosas semanas e incluso de meses, en el que se implicaban un buen número de personas entre oficiales, financieros, licitadores, testigos, fiadores y fieles ${ }^{27}$. Para que este sistema funcionase de forma debida, todos los agentes fiscales - que iban desde el arrendador mayor hasta el perceptor o cogedor encargado de cobrar el tributo- colaboraban en el complejo régimen de arrendamiento, recibiendo por su participación una serie de beneficios acordes a su implicación en el sistema.

Por todo ello, el arrendamiento de rentas encubría una realidad mucho más amplia y compleja que la de una relación contractual entre la Corona y el arrendador. El suculento negocio que suponía el arrendamiento de rentas regias, permitía a los grandes arrendadores y principales compañías financieras, desplegar una serie de estrategias con las que poder acaparar el mayor número de rentas posible y mantener a un enorme grupo de hombres que vivían del lucrativo negocio del arrendamiento.

El estrado de las rentas se convertía en el lugar ideal para desplegar todo tipo de estratagemas -más o menos lícitas- que perseguían un objetivo muy concreto: obtener las rentas en las mejores condiciones y al mejor precio posible.

Era aquí, donde debían acudir todos los licitadores para hacer sus ofertas, mejorar las pujas e intentar conseguir los incentivos que ofrecía la Corona a todos aquellos que participaban en el juego de la subasta: los prometidos y las cuartas partes de pujas. Solía ser el espacio en el que se decidía finalmente quién sería el arrendador mayor, quiénes serían sus fiadores y quién ejercería la fieldad hasta que el proceso de arrendamiento pudiese darse por concluido ${ }^{28}$.

en su origen como financieros) también ha sido abordada por nosotros A. ORTEGA, La Fiscalidad Regia en el Obispado de Granada, op. cit.

${ }^{27}$ Las subastas de rentas han sido bien descritas -tanto las regias como las concejiles- en: A. ROMERO MARTÍNEZ, Proceso recaudatorio y mecanismos fiscales en los concejos de la Corona de Castilla, "Anuario de Estudios medievales", 22, (1992), pp. 739-765; Los papeles del fisco. Estudio diplomático de la documentación fiscal castellana bajomedieval, Granada, 1998; Fisco y recaudación. Impuestos directos y sistema de cobro en la Castilla medieval, Granada, 1999; La intervención de los agentes del fisco castellano, op. cit. pp. 68-71; M.A. SoliNis, La Alcabala del Rey (1474-1504), op. cit. pp. 105-115; A. ORTEGA, La Fiscalidad Regia en el Obispado de Granada, op. cit; A. COLLANTES DE TERÁN SÁNCHEZ, El sistema de arriendo de las rentas concejiles en las ciudades andaluzas, op. cit. pp. 199-205. Este último autor -como muestra de la cantidad de personas que podían participar en una subasta de rentas (en este caso concejiles)nos ofrece los siguientes datos: En la Sevilla del siglo XV se hacían sesenta y cuatro arriendos anuales sin contar los de la tierra, los cuales se transformaron en ciento cuarenta y seis operaciones. En cuanto al número de personas implicadas, en Carmona lo fueron doscientas cincuenta y nueve en una veintena de años y en Jerez ciento sesenta y cinco para un total de cincuenta y dos arriendos, p. 193.

${ }^{28}$ Decimos "solía" porque posteriormente podían admitirse traspasamientos y cambios en los fiadores. Lo que sí permanecía exactamente igual son las fieldades. El régimen de fieldad, además de ser un procedimiento que se ponía en funcionamiento cuando las rentas no habían logrado arrendarse, era un sistema de percepción ordinario utilizado anualmente para cubrir el breve 
La actuación en el Estrado de las Rentas suponía la piedra angular del negocio del arrendamiento. Por ello, lejos de ser un sistema transparente que acababa beneficiando al mejor postor ${ }^{29}$, el sistema de pujas al alza desarrollado en dicho lugar terminaba convirtiéndose en un auténtico avispero en el que habitaban diferentes artimañas, ardides y celadas.

\section{EL FRAUDE EN LAS SUBASTAS DE LAS RENTAS A TRAVÉS DE LA LEGISLACIÓN HACENDÍSTICA}

Por quanto nos es fecha relaçion que algunos recabdadores mayores e menores en la nuestra corte o fuera della e otras personas hasen fraudes $e$ ligas para que algunos no arrienden e pujen las nuestras rentas asy en la nuestra corte por mayor como fuera della por menor, de lo qual a nos se sigue deserviçio e diminuçion en nuestra renta ${ }^{30}$.

La preocupación de la Corona y los reiterados intentos por su parte de convertir la subasta de las rentas en algo limpio, transparente y accesible a todos aquellos que quisiesen participar en ella, es algo que podemos rastrear en la legislación hacendística al menos desde los últimos Trastámaras.

A través de los llamados cuadernos de rentas ${ }^{31}$, los sucesivos reinados castellanos fueron legislando e incorporando una normativa, en la cual se regulaban -entre otras muchas cuestiones ${ }^{32}-$ los derechos y las obligaciones contraídas entre la Corona y los arrendadores. Se trataba de una compilación de reglas y de normas que regularizaban el proceso de arrendamiento, y que se iban actualizando con el paso de los años ${ }^{33}$. Conforme se iban sucediendo los reinados, los cuadernos presentaban una serie de modificaciones con respecto a sus antecesores, que iban encaminadas a controlar las crecientes corruptelas, los fraudes fiscales y a solucionar ciertos problemas que iban

periodo de tiempo que transcurría entre la subasta y la obtención de la carta de recudimiento. Por ello, la figura del fiel podía desempeñar labores claves en el proceso de arrendamiento. Profundizamos mucho más en este asunto en A. ORTEGA, La Fiscalidad Regia en el Obispado de Granada, op. cit.

29 "Las arrendades e remates en quién más por ellas diere” Salvador DE MoXó, Los cuadernos de alcabalas. Orígenes de la legislación tributaria castellana, "Anuario de Historia del Derecho Español", XXXIX (1969), p. 383.

${ }^{30}$ M.A. LADERO, Legislación hacendística, op. cit. Cuaderno del año 1491, disposición 41, p. 142. La cursiva es nuestra.

${ }^{31}$ Aunque los más conocidos e importantes son los cuadernos de alcabalas, tercias y monedas, también tienen su importancia los cuadernos de aduanas, servicio y montazgo, salinas- alfolíes y moneda forera. M.A. LADERO, Legislación hacendística, op. cit. pp. 16-21.

${ }^{32}$ Quiénes debían pagar la renta y quiénes estaban exentos de su pago, cómo debía percibirse, o mecanismos de control para asegurarse que todo el mundo contribuía con la parte que le correspondía. S. DE Moxó, Los cuadernos de alcabalas, op. cit. pp. 329-330.

${ }^{33}$ Salvador DE Moxó resaltó las características más importantes de cinco cuadernos de alcabalas redactados entre los reinados de Enrique II y los Reyes Católicos: 1377, 1430, 1462 , 1484 y 1491 . Ibíd. pp. 317-367. 
surgiendo con el transcurrir del tiempo, lo que suponía normas cada vez más duras y más estrictas ${ }^{34}$.

Son los cuadernos de alcabalas aquellos que presentan la normativa más completa, más acabada y mejor sistematizada de toda la legislación tributaria, pues aunque estaban destinados a regular la gestión y la percepción de dicho impuesto, muchas de las normas podían extenderse a todas las demás rentas, impuestos y derechos pertenecientes a la Corona ${ }^{35}$.

Sin que falten los cuadernos de monedas y tercias - a los cuales también prestaremos atención- será la larga serie de cuadernos de alcabalas iniciada formalmente en 1377 y finalizada en 1491, la que constituya la guía básica a través de la cual poder identificar las prácticas fraudulentas que cuaderno tras cuaderno y reinado tras reinado, seguían denunciándose por parte de los monarcas ${ }^{36}$.

Dentro de esta legislación encontramos varios capítulos dedicados a la forma en la que los aspirantes a arrendadores podían o no podían proceder en las subastas de las rentas. Más que una relación o descripción que perfilase o ayudase a sistematizar el procedimiento de pública almoneda, los cuadernos exponían y denunciaban ciertas prácticas tildadas de fraudulentas. La mayoría de ellas aparecen localizadas y debidamente sancionadas desde el cuaderno de alcabalas de Enrique IV, sin embargo, y a pesar de ello, los cuadernos posteriores continúan haciendo alusión una y otra vez a las mismas corruptelas, prueba de que el fraude en el Estrado de las Rentas era uno de los objetivos prioritarios a combatir.

Tres parecen ser los ámbitos principales en los que la Corona no lograba atajar la corrupción en el Estrado: el acceso a la subasta en la que se decidían los arrendamientos al por mayor, las estafas que proliferaban en el proceso de subarrendamiento y la utilización de testaferros con fines fraudulentos. Veámoslos.

\footnotetext{
${ }^{34}$ Un ejemplo de esto son las nuevas normas que Juan II incorporó en los cuadernos de rentas para evitar los impagos de los arrendadores y sus fiadores, pues en los cuadernos anteriores ni las fianzas ni los avales que debían presentar estos personajes estaban regulados ni asentados. M.A. LADERO QUESADA, Instituciones fiscales y realidad social en el siglo XV castellano, en El siglo XV en Castilla. Fuentes de rentas y politica fiscal, Barcelona, 1982, pp. 64-65. En el año 1411 -en un cuaderno de rentas concejiles de la ciudad de Sevilla- se hace alusión a esta nueva norma: "por lo qual la dicha çibdat perdió algunas de las dichas sus debdas, por non tener los contadores de Seuilla fe de las obligaciones que cada arrendador fasía por la rrenta”. A. COLLANTES DE TERÁN SÁNCHEZ, El sistema de arriendo de las rentas concejiles en las ciudades andaluzas, op. cit. p. 195.

35 "Y esta misma orden mandamos que tengan los nuestros contadores mayores e sus lugarestenientes en las rentas que se arriendan en el nuestro estrado asy de estas alcabalas como de otras cualesquier rentas". M.A. LADERO, Legislación hacendística, op. cit., cuaderno de 1484, disposición 120, p. 218. La cursiva es nuestra.

${ }^{36}$ Una buena parte de estos cuadernos están editados. Salvador DE Moxó editó el cuaderno de alcabalas de 1462: Los cuadernos de alcabalas, op. cit. y Miguel Angel Ladero Quesada -entre otros- los de 1484 y 1491, M. A. LADERO, Legislación hacendística, op. cit. A partir de ahora citaremos a estos autores para aludir a determinadas disposiciones dictadas en dichos cuadernos.
} 


\section{El arrendamiento al por mayor}

El principal objetivo para todo hombre de negocios que utilizaba el arrendamiento de rentas regias como vía principal para aumentar y consolidar su poder tanto económico, como social o político ${ }^{37}$, era llegar a ser nombrado arrendador-recaudador mayor de determinadas rentas regias ${ }^{38}$. El verdadero negocio comenzaba en ese momento, por lo que se hacía indispensable conseguir dicho nombramiento. De ahí, que el fraude en esta primera etapa del proceso estuviese tan extendido, pues cualquier maniobra era válida para los financieros si se conseguía el objetivo previsto: impedir que el rival se hiciese con las rentas.

1) Los financieros más importantes y poderosos intentaban controlar las subastas impidiendo que accediesen a ella el resto de participantes. La coacción solía realizarse a través de sobornos, ofreciéndoles ciertas cuantías de maravedíes, la cesión de los prometidos - o cuartas partes de pujas - o asegurándoles parte de los beneficios en las rentas. Todo ello a cambio de una contraprestación: no participar en la subasta de las rentas ${ }^{39}$.

2) Una segunda maniobra estaban dispuestos a realizar estos agentes del fisco si la primera había resultado infructuosa. Dado el caso de que las rentas ya estuviesen puestas en precio o rematadas de primer remate, estos arrendadores intentaban asociarse de alguna forma -ofreciéndose como fiadores o socios arrendadores- para poder participar en el arrendamiento de las rentas ${ }^{40}$.

El más perjudicado de todos era el Fisco Regio pues estas maniobras coartaban la libertad a los licitadores, "por lo qual los que las querían pujar o ellos mismos se retraen" ${ }^{41}$, las pujas quedaban muy limitadas y las subastas no ofrecían el resultado deseado ${ }^{42}$. La solución pasaba por prohibir y condenar unas prácticas que aunque vigentes desde hacía décadas, los monarcas

${ }^{37}$ Hasta el punto de que algunos de los testigos que colaboraban en la información de bienes declaraban abiertamente que era de ello de lo que vivían. Era el caso de Pedro de Santa Cruz y Francisco de Mena. Máximo DIAGO HERNANDO, Arrendadores arandinos al servicio de los Reyes Católicos, "Historia Instituciones y Documentos", 18 (1991), pp. 82-83, o de Fernando de Villarreal' del cual decían "es recaudador e biue por' recaudador" Archivo General de Simancas (AGS), Escribanía Mayor de Rentas (EMR) leg. 550, s.f. fiador.

${ }^{8} \mathrm{O}$ conseguir que lo hiciera alguien muy próximo a él, para poder desempeñar el "oficio" de

39 “Otro sy por quanto nos es fecha relación que algunas personas vienen ante los nuestros contadores mayores a arrendar e pujar algunas rentas, e otros que las tienen puestas en presçio o las han pujado, e les prometen e dan dadivas e intereses porque no las pujen ni fablen en el arrendamiento dellas". M.A. LADERO, Legislación hacendística, op. cit. , cuaderno de alcabalas de 1491, disposición. 51, p. 142. La cursiva es nuestra.

40 “O se abienen contra los que las tienen puestas en presçio e pujadas para les dar e tomar alguna parte de las dichas rrentas con ellos" Ibíd.

${ }^{41}$ Ibíd.

${ }^{42}$ La finalidad era lograr que el precio del arrendamiento alcanzase el valor más alto posible. Jean FAVIER, Finances et fiscalité au bas moyen Age, París, 1971, pp. 227-228. 
esperaban que pudiesen adecuarse al rigor con el que operaba la Hacienda Regia en época de los Reyes Católicos ${ }^{43}$.

\section{El arrendamiento al por menor}

En todo el transcurso del arriendo, el arrendamiento al por menor -o también llamado subarrendamiento- constituía la pieza clave de todo el proceso. Era para el arrendador mayor la operación más importante de todas, ya que de él dependían una buena parte de los beneficios obtenidos por responsabilizarse de recaudar unos tributos determinados ${ }^{44}$.

Esta fase se iniciaba una vez que se había elegido a un arrendador recaudador mayor en el Estrado de las Rentas, momento en el que él, o el fiel correspondiente, tenía la autorización para comenzar a arrendar al por menor las rentas de su partido: era el momento de empezar a colocar las fichas en el tablero.

El objetivo en esta etapa del arrendamiento estaba muy claro, aunque los caminos para llegar a él pudiesen ser de lo más diversos, pues los intereses de cada sociedad, compañía, agrupación o arrendador eran de lo más variado.

1) Si el arrendador mayor quería quedarse con una gran parte $-\mathrm{o}$ al menos con algunas - de las rentas que se subastaban por menudo, debía evitar las pujas. Una de las formas de hacerlo era pregonar unas condiciones de arrendamientos falsas, que se caracterizaban por introducir ciertas cláusulas que obligaban al que se convirtiese en arrendador menor a pagar ciertos sobreprecios. De esta forma se espantaba a los licitadores, pues arrendar las rentas con estas condiciones suponía para los aspirantes un gran desembolso económico ${ }^{45}$. En esta situación solamente los arrendadores mayores sus socios y compañeros, conocerían las verdaderas condiciones del arrendamiento, siendo ellos los únicos dispuestos a pujar por ellas: el arrendador mayor se aseguraba el control total de las rentas y eliminaba la competencia. En el

\footnotetext{
43 "Por ende queriendo en ello remediar, ordenamos e defendemos que ninguno no sea osado de estorvar a otro de pujar qualquier renta que el toviere puesta en presçio o pujado en qualquier manera, ni los que començaren a fablar en algunas rentas deseen de las pujar por fraudes o ligas ni por dádivas ni intereses que les sean dados prometidos de qualquier calidad que sean" M.A. LADERO, Legislación hacendística, op. cit. cuaderno de alcabalas de 1491, disposición. 51, p. 142.

${ }^{44} \mathrm{Al}$ menos los que generaban una ganancia económica inmediata y los que permitían que sus productos ocuparan una posición inmejorable en la producción y el tráfico mercantil. El resto de beneficios son más difíciles de medir ya que pueden estar relacionados con el prestigio, la posición social, etc.

45 "Por quanto somos informados que los nuestros arrendadores e recabdadores mayores e otros fazedores de nuestras rentas fasen e acostumbran a faser fraudes e colusyones en ellas poniendo por condiçion e fasiendo pregonar que qualquier que arrendare las dichas rentas por menor pague de derechos de mas del preçio en que las pusyere çierta contia de maravedies con cada millar e algunas gallinas e otras cosas, e otros eçebtan algunas personas quando hasen las rentas por menor para que sean francos de alcabalas de lo que conpraren e vendieren o que no entre en el arrendamiento para arrendar su alcavala por otra parte, lo qual es en grand deserviçio nuestro e desminuçion de las dichas nuestras rentas porque algunos dexan de las pujar a causa e los dichos derechos e gallinas e a causa de eçebtar las tales personas e de aquello no se haçe mençion en el recabdo que de las dichas rentas hasen ni juntan el acresçentamiento con los otros maravedíes que por la dicha renta han a dar" M.A. LADERO, Legislación hacendística, op. cit., cuaderno de alcabalas de 1491 , disposición 65, p. 158.
} 
improbable caso de que alguna persona pujase, a pesar de las condiciones pregonadas, el arrendador se embolsaría una serie de beneficios íntegros para él, pues al ser falsas estas condiciones y no quedar reflejadas en ningún documento oficial, el dinero se le escapaba a la Hacienda de forma fraudulenta.

Sin embargo -y contra lo que pudiera parecer- la verdadera ganancia de esta táctica no estaba tanto en el control de la renta o en el sobreprecio, sino en el provecho que esta estrategia les reportaría en los años sucesivos $^{46}$. Al haber sido tan bajo el precio alcanzado en el arrendamiento al por menor (pues había sido una subasta casi carente de pujas), al año siguiente las rentas partían en la subasta al por mayor de un precio mucho menor que el de los años anteriores. Esto permitía a los arrendadores obtener las rentas a un bajo precio y subarrendarlas a los precios reales, obteniendo así un margen de ganancia muy elevado ${ }^{47}$.

2) Otra forma de asegurarse el control de las rentas era no realizar el subarrendamiento y adjudicar directamente las rentas ${ }^{48}$. Sencillamente obviaban el proceso de las pujas al alza y nombraban a los arrendadores menores sin seguir el procedimiento legal; algo prohibidísimo pero que los arrendadores solían realizar con cierta asiduidad ${ }^{49}$.

3) En otras ocasiones decidían seguir el proceso estipulado pero falseando los plazos, los pregones y los remates. De esta forma -y una vez rematada la renta al por menor - el arrendador siempre podía alegar que el remate de la renta no era válido por no haber guardado los plazos concertados. Con esta maniobra el arrendador mayor ganaba tiempo para tener ciertos conocimientos de la ganancia que dicha renta podía ofrecer ${ }^{50}$, adjudicándola posteriormente -si así lo decidía- a alguno de sus hombres ${ }^{51}$.

\footnotetext{
${ }^{46}$ Pues era muy común que los arrendadores arrendaran las rentas por un mínimo de dos años.

47 "E a las dichas rentas viene disminución e asy vienen menguadas las copias de los nuestros escrivanos mayores de rentas, por lo qual nuestros contadores mayores arriendan por mayor las dichas rentas a menos presçio de lo que valieron e pudieran valer el año antepasado con los dichos derechos e gallinas por no venir en las dichas copias e por no entrar todos en el arrendamiento" M.A. LADERO, Legislación hacendística, op. cit., cuaderno de alcabalas de 1491, disposición 65 , p. 158 .

48 "E una de las cosas porque esto acaeçe es por arrendar ellos las dichas rrentas que se arriendan a menudo syn puja mayor nin menor", S. DE MOXó, Los cuadernos de alcabalas, op. cit. p. 435.

49"Porque podria acaeçer que algunos de los dichos arrendadores mayores aunque no se nonbren por arrendadores menores de las rentas que quieren tomar para sy nombran onbres suyos e otros que no son abonados por arrendadores dellas e les dan recudimientos e contentos con que cojan las dichas rentas syn tomar dellos las dichas fianças, e algunos de los tales o otros por sus poderes las cogen para los dichos arrendadores mayores o para sy por ynterese que dan a los dichos arrendadores mayores, lo qual sy asy pasase seria engaño manifiesto e los que tienen previllejos sytuados e salvados en las dichas rentas no ternian de quien los cobrar (...)" Ibíd.

${ }^{50}$ Vid. nota 56.

51 "Por quanto nos es fecha relacion que algunos nuestros arrendadores e recaudadores mayores por defraudar los arrendadores menores dexan de haser los remates de las rentas que se hasen por menor segund e como deven no guardando en los tales remates los pregones que primero se han de dar por la forma que por las leyes deste nuestro cuaderno se deven guardar para ello, e de aquí resulta que después de rematada por menor la tal renta de todo remate en el arrendador menor e sacado ya el recudimiento e fechas algunas ygualas se da la tal renta a otro disendo que no valio el remate", M.A. LADERO, Legistación hacendística, op. cit., cuaderno de alcabalas de 1491, disposición 66 bis, p. 160.
} 
4) La puja de cuarto $^{52}$ era la última oportunidad a la que podía optar el pujador -tanto en el arrendamiento al por mayor como al por menor-para lograr convertirse en el arrendador de la renta. Estas pujas solamente podían llevarse a cabo tras el postrimero remate: momento en el que se abría un corto plazo de tiempo para realizarlas ${ }^{53}$.

En los cuadernos de rentas proliferan las denuncias relacionadas con estas pujas y con el aprovechamiento que realizan los arrendadores mayores de su cargo y posición a la hora de realizarlas. Una vez que el subarrendamiento de las rentas podía darse por finalizado ${ }^{54}-\mathrm{y}$ teniendo en cuenta la información privilegiada de la que disponían los arrendadores mayores- estos intentaban quedarse con las rentas ya rematadas al por menor, bien sobornando a ciertos personajes para que en su nombre realizasen las pujas de cuarto, bien enviando a "omes suyos"

Al igual que ocurría con el arrendamiento al por mayor, la más afectada y dañada por estos fraudes eran las Arcas Regias ${ }^{57}$. Por ello, la Corona intentaba establecer medidas para combatir las infracciones, que pasaban por ganarse la confianza de los arrendadores menores (pues se les eximía completamente de culpa) y castigar a los arrendadores mayores ${ }^{58}$.

\footnotetext{
${ }^{52} \mathrm{Su}$ nombre se debe a que la puja no podía superar el valor de la cuarta parte del precio de la renta.

${ }^{53}$ Los plazos se fueron modificando con el tiempo. Este sistema aparece por primera vez mencionadó en el cuaderno de alcabalas de 1462 y se regularizó en las Cortes de Nieva de 1473 M. A. Solinís, La Alcabala del Rey (1474-1504), op. cit. p. 122. Aunque hay que esperar a reinado de los Reyes Católicos para que funcione con normalidad. Algunos ejemplos en: AGS, Escribanía Mayor de Rentas Incorporados (EMR-I-) leg. 35. ff. 130r-140v; EMR, leg. 65. ff. $807 r-812 r$.

${ }^{54}$ Con la expresión en la documentación Rematado de todo remate.

${ }^{55}$ Esta actuación también está relacionada con la que veremos a continuación: los testaferros. La expresión omes suyos, era utilizada por los documentos de la época. Vid. notas 49 y 65.

56“Porque nos es fecho saber que algunos de los nuestros arrendadores e recaudadores mayores aviendo rematadas algunas rentas menores de todo remate conociendo que los arrendadores menores han dellas algund provecho procuran de gelas quitar y ellos mismos dan quien faga el dicho cuarto de puja en las dichas rentas por ellos, o dan e prometen dadivas a quien lo haga o dan cartas de pago de alguna parte del dicho quarto, de que recibe agravio aquel en quien estava rematada la dicha renta" M.A. LADERO, Legislación hacendística, op. cit., cuaderno de alcabalas de 1484, disposición 120, p. 218.

57 "E esto es muy grand deserviçio nuestro (...) por ende mandamos que ningund arrendador mayor ni menor no arriende ninguna renta con tal condiçion que sea syn puja mayor ni menor ni faga ninguna encubierta, sy no, cualquier que quisiere pueda haser puja en tiempo devido (...) e mandamos a los nuestros arrendadores mayores que sean tenudos de las reçebir" "Por ende, defendemos e mandamos que ninguno ni algunos arrendadores ni recaudadores ni hacedores de rentas no seạn osados de poner ni pongan en este año de noventa e dos ni dende en adelante las tales condiçiones (...) ni reçiban maravedíes algunos ni gallinas ni otras cosas publica ni secretamente, directe ni yndirecte de más e allende del presçio principal porque públicamente arrendaren las dichas nuestras rentas", , M. A. LADERO, Legislación hacendística, op. cit., cuaderno de alcabalas de 1491, disposición 71, p.163.

58 "E porque podría ser que este fraude se hisiese encubiertamente, mandamos que para este caso el testimonio e confisyon de tres o a lo menos dos personas aunque sean los mismos arrendadores menores de un tienpo o de diversos que participaren en el dicho fraude fagan fe e provança conplida contra el dicho arrendador e recaudador mayor", Ibíd. disposición 61, p. 159. Con respecto a las pujas de cuarto: "E sy se fallare que yntervinieron dadivas o promesas o cartas de pago o otros ynterese directe o yndirecte de cualquier calidad que sea, por faser el dicho quarto, que aviendo los tales casos o cualquier dellos no pueda ser quitadas las dichas rentas a los que las tovieren arrendadas e que fasta haser el dicho juramento e declaración no sean desapoderados los arrendadores de las dichas rentas", Ibíd. Cuaderno de 1484, disposición 120, p. 218 .
} 


\section{Los testaferros}

Otro de los problemas al que tuvieron que enfrentarse los monarcas fue a la presencia de los testaferros, pues aunque su asistencia y participación en las subastas estaba permitida, en algunas ocasiones estos personajes eran utilizados con fines ilícitos. Cualquier persona podía pujar en nombre de otra, estando dicha situación completamente aceptada dentro de la normativa y de la legalidad ${ }^{59}$. El problema surgía cuando estas personas interpuestas eran utilizadas por los licitadores para obtener ciertas ventajas sobre el resto de los pujadores.

Los cuadernos de rentas fueron habilitando con el tiempo determinados lugares en los que poder presentar las pujas correspondientes. Realmente casi cualquier lugar de la Corona castellana era aceptado para recibir pujas - siempre y cuando se hiciese ante un escribano ${ }^{60}$ - pues tal y como expresaban los propios cuadernos, la intención era que "todos los que quisieren pujar tengan libertad para pujar la contía que quisieren ${ }^{61}$ ". Sin embargo tanta facilidad acabó convirtiéndose en enemiga de la Corona, pues los arrendadores encontraban en dicha disposición campo abonado para acometer todo tipo de conspiraciones.

1) Poder presentar pujas en diferentes lugares de la Corona beneficiaba fundamentalmente a las grandes compañías o a los grandes arrendadores, que tenían a su servicio una importante red clientelar repartida por una buena parte de la geografía castellana. Como las principales pujas se realizaban habitualmente en la Corte o en el lugar donde se colocaba oficialmente el Estrado de las Rentas ${ }^{62}$, los principales financieros curtidos en el proceso solían permanecer aquí.

Los plazos en los que las rentas se remataban tanto de primero, como de postrimero y de todo remate eran conocidos por todos los presentes, pues era una obligación de los Contadores o de sus lugares tenientes hacerlos

59“(...) Yo Pedro de Cardenas, vezino de la noble honrrada e gran çibdad de Granada otorgo e conosco que por quanto yo fui a la Corte del Rey e de la Reyna nuestros señores a pujar e poner en presçio çiertas rentas pechos e derechos a sus altesas pertenecientes este presente año del señor de mill e quatrocientos e noventa e cinco años para vos Cadi Mahamad Aduladin e Nycolas Lopez de Spindola vezıno desta dicha çibdad e por vuestro mảndado yo puje y fueron rematadas en my las rentas (...)" AGS, EMR-I leg. 24, f. 18r.

${ }^{60}$ Es esta una disposición que aparece muy bien recogida, y detallada, desde cuadernos muy tempranos. La hemos hallado en el cuaderno de monedas del año 1381 -reproducido íntegramente por D. MENJOT, Fiscalidad y Sociedad. Los murcianos y el impuesto en la baja Edad Media, Murcia, 1986, documento III, pp. 371-372- y posteriormente en el cuaderno de alcabalas de Enrique IV, S. DE MOXÓ, Los cuadernos de alcabalas, op. cit. p. 388.

${ }^{61}$ M.A. LADERO, Legislación hacendística, op. cit., cuaderno de alcabalas de 1491 , disposición 53, p. 144.

${ }^{62}$ Aunque luego podían haber varios estrados. El proceso, desde que se aceptaban las primeras posturas hasta que eran rematadas de todo remate, se realizaba en diversos lugares, lo que significa que podían levantarse diversos estrados en distintas ciudades, moverse dentro de la misma ciudad o habilitarse varias zonas en las que los ponedores y los pujadores pudiesen presentar sus ofertas. A. ORTEGA, La Fiscalidad Regia en el Obispado de Granada, op. cit. 
públicos $^{63}$. Con esta información los principales ponedores de las rentas daban órdenes muy precisas a sus socios, amigos, o compañeros, para que a una hora determinada - cuando estaba a punto de terminarse el plazo ${ }^{64}$ - y en un lugar alejado de la Corte, hiciesen una última puja. Esta operación sería desconocida en la Corte y la subasta de las rentas se daría finalmente por concluida a la hora y en el día fijados. El personaje encargado de realizar la última operación podía irse a casa con la tranquilidad de saber que la renta finalmente sería para él. Pocos días después llegaría a la Corte la noticia de esta última puja, teniendo que ser aceptada - tal y como lo reflejaba la normativa-.

El único lugar en el que hemos encontrado esta práctica minuciosamente detallada, es en el cuaderno de los diezmos y aduanas de los Obispados de Calahorra, Osma y Sigüenza del año $1446^{65}$. Aquí se exponía la problemática $^{66}$ y se intentaba trazar una solución para un problema muy difícil de atajar, pues prohibir las pujas fuera de la Corte iba en contra de los intereses del monarca y permitirlas con tanta flexibilidad daba lugar a los más diversos fraudes; por ello la medida adoptada por el monarca y sus sucesores podemos calificarla de intermedia. Las pujas seguirían siendo aceptadas - con independencia de lo lejana que pudiese ser su procedencia- con una condición: los pujadores debían jurar antes de participar en la subasta que no tenían ninguna relación con los financieros que en esos momentos estaban operando en la Corte. Se prohibía a los licitadores que estuviesen presentes en la Corte en el momento de abrir el plazo de las pujas, que enviasen a sus hombres fuera ${ }^{67}$.

63 “Que antes que los nuestros contadores mayores reçiban la postura de cualquier renta fagan e publiquen las condiçiones con que la arriendan”", M.A. LADERO, Legislación hacendística, op. cit., cuaderno de alcabalas de 1484, disposición 122, p. 218.

${ }^{64}$ Pues había normas muy estrictas para que no pudiese hacerse después.

65 “Por quanto me fue fecha relación que quando se cunple el plaso en que pueden ser rescebidas pujas en las mis rentas que algunos cabtelosamente o por quedar con algunas de las dichas rentas porque otros no las puje sobre el o porque la puja que fesiere venga sobre las que se fesieron en el mi estrado la postrimera noche que se cumplen las dichas pujas, que envían a otra cibdad o villa o lugar fuera de la dicha mi corte a algunos omes suyos o otros quales ellos entienden que les cumplen, lo mas alexos que ellos pueden faser la dicha puja o media puja e que la fasen sobre todas las pujas o medias pujas que se fiesieron en las dichas rentas la dicha postrimera noche en el dicho mi estrado o en otra parte fuera de la dicha mi corte que fueron presentadas ante los mis contadores" M.A. LADERO, Legislación hacendística, op. cit., cuaderno de arrendamiento de los diezmos y aduanas de los Obispados de Calahorra, Osma y Sigüenza del año 1446 , disposición 60 , pp. 287-288.

66 "E ademas desto algunos que tyenen la dicha renta en sy rematada o por puja pensando que está seguro porque no la pujó sobre él en la dicha mi corte o en el dicho mi estrado ni cura de la pujar, e sy la puja fụese fecha en la dicha mi corte o en el dicho mi estrado sobre el pujaría la tal persona que asy fesiese la dicha puja sobre el, e después el otro sabiendo que la dicha puja que el enviase faser fuera de la dicha mi corte no le avria de valer pujaria sobre el dicho arrendador en tal manera que la renta valdría mas e se farian en ellas más pujas" Ibíd. p. 288.

67 "Por ende es mi merçed e mando que en caso que algunas personas o personas enbiaren a faser la dicha puja o media puja en esta dicha renta a otro lugar de los mis regnos fuera de la dicha mi corte, sy fuere sabido o probado que las dichas personas que asy fueren o enbiaren faser la dicha puja estavan en la dicha mi corte e la enviaban a faser fuera porque la dicha renta quedase con ellos, segund, segụnd dicho es, que les no sea resçebido e que la paguen a my por sy e por sus bienes. Pero es mi merçed que sy otra persona alguna de algunas çibdades e villas e lugares de los mis regnos de los que no estan en la dichas mi corte so entençion de arrendar la dicha renta fesieren la dicha puja o media puja, que les sea resçebida fasiendo juramento que 
2) Los cuadernos de alcabalas de 1462, 1484 y 1491 dedican algunos capítulos a una cuestión similar, pues si bien no se refieren específicamente a las estrategias que se realizan justo la última noche en la que se cumple el plazo, advierten sobre los fraudes que se realizan a través de testaferros para pujar en las subastas. Para evitarlos se promulgaron las siguientes leyes: 1) Las pujas que se hiciesen en la Corte prevalecerían sobre las que se realizasen fuera de ella ${ }^{68}$-siempre y cuando fuesen de la misma cantidad ${ }^{69}-$. 2) Todo aquel que pujase fuera de la Corte estaba obligado a presentar la puja ante los Contadores Mayores en un plazo determinado ${ }^{70}$; medidas que contribuían a controlar las subastas y a evitar lo denunciado en el cuaderno de 1446.

Todas y cada una de las actuaciones que hemos analizado aquí - y que reflejaron y denunciaron los cuadernos de rentas- respondían a una misma preocupación: mermaban las pujas y paralizaban un proceso que se había ideado para que fuese activo, dinámico y muy participativo.

\section{DE LA LEGISLACIÓN A “LA CALLE”: ALGUNOS EJEMPLOS}

Estos individuos deberían, en realidad, ser llamados malhechores, prevaricadores, traficantes ilegales, malos sujetos y hez de la sociedad, pues no tienen miedo ni vergüenza, ni otra religión o piedad que buscar las ventajas de la vida terrestre y vivir de beneficios ilícitos y de la usura ${ }^{71}$.

Que el sistema de arrendamientos era un sistema tremendamente complejo, es algo a lo que ya hemos aludido con anterioridad y a lo que han hecho referencia otros muchos autores ${ }^{72}$. Su complejidad residía tanto en el intrincado itinerario que el licitador debía recorrer hasta convertirse en arrendador, como, sobre todo, en ciertas prácticas a las que no encontramos

la no fesieron para ninguna persona que en la dicha mi corte estuviese ni por su consejo ni por la dicha cabtela $e$ todo esto sobredicho se entienda en las pujas que fesieren la dicha postrimera noche que se cumplen las dichas pujas. Ibíd. La cursiva es nuestra.

68 “Por sy se fesieren pujas o medias pujas o mas en la mi Corte e otro sy fuera de la mi Corte es mi merced que la primera puja o pujas que primero se presentaren ante los mis contadores mayores o en su absençia ante sus lugarestenientes non estando presentes algunos de los dichos mis contadores menores como dicho es que aquella vala caso que la otra sea fecha primeramente o en ese mismo día", S. DE MOXó, Los cuadernos de alcabalas, op. cit. p. 431.

69 "E esto se entienda seyendo yguales en quantia. E sy fuere de mayor quantia que aquella vala", Ibíd.

70 "E fecha la dicha puja que la muestre e presente el que la fisiere ante los mis contadores mayores o en su absençia ante sus lugarestenientes (...) e sy en este plaso la non mostrare y presentare que non bala la puja o media puja o mas que oviere fecho e finque la tal rrenta en el arrendador primero en que estava primeramente la dicha renta" Ibd, 431. Disposición que vuelve a aparecer en el cuaderno de 1491 M.A. LADERO, Legislación hacendística, op. cit., disposición 53 , p. 145 .

${ }^{71}$ Ibn ABDUN, Sevilla a comienzos del Siglo XII. (E. GARCÍA GOMEZ; E. LEVÍ-PROVENÇAL, eds.), Sevilla. 1981, pp. 43-44.

72 "No ha de pensarse, sin embargo, que la puesta en marcha de un arrendamiento era tan sencilla", M.A. LADERO, La Hacienda Real de Castilla, op. cit. p. 26. "Ante el panorama descrito hasta el momento, se habrá de convenir en la tremenda dificultad y complejidad de los procesos de arrendamiento". A. ROMERO MARTÍNEZ, La intervención de los agentes del fisco castellano, op. cit. p. 83. 
a priori una explicación ¿Por qué las rentas acababan traspasándose cuando el arrendador había conseguido un buen precio por ellas? ¿Por qué ciertas rentas no alcanzaron el precio deseado a pesar de ser rentas muy importantes y contendidas? ¿Por qué la ausencia de licitadores en determinadas subastas? ¿Por qué varios arrendadores que se habían estado disputando las rentas en el Estrado acababan colaborando juntos en ese arrendamiento? ¿Por qué un mismo arrendador seguía arrendando año tras año ciertas rentas, cuando lejos de obtener beneficios todo eran pérdidas?

La respuesta a todas estas preguntas se encuentra en las maniobras -lícitas o ilícitas - que las compañías de arrendadores desplegaban en varias fases del arrendamiento ${ }^{73}$. Solamente el seguimiento minucioso de las actuaciones de ciertos arrendadores y compañías, el análisis de algunas subastas de rentas o el hallazgo de algunos pleitos $^{74}$, pueden ayudarnos a resolver cuestiones como estas, pues la mayoría de las estrategias se esconden tras un halo de legalidad que nos impide comprobar si estamos ante un fraude, o simplemente ante estrategias complemente lícitas que forman parte del engranaje del sistema: pujar con fines especulativos, traspasos de rentas, etc.

En el presente apartado intentaremos mostrar cómo las prácticas denunciadas en la legislación hacendística, se pueden palpar más allá de la teoría y las generalidades reflejadas en los cuadernos. Arrendamientos concretos, arrendadores con nombres y apellidos y situaciones reales, nos permitirán reconstruir algunas subastas de rentas llevadas a cabo con mecanismos que podemos calificar, cuanto menos, de dudosa legalidad.

A finales del s. XV las principales rentas castellanas estaban en manos de grupos de financieros que intentaban monopolizar el negocio fiscal casi por completo. Tal era el caso de la conocida compañía formada por Rabí Mayr, Abraham Seneor, Abrahem Bienveniste y el converso Luís de Alcalá, o la considerada "compañía rival" formada por Alonso Gutiérrez de Madrid, Juan Díaz de San Ginés, Fernando de Villarreal y García de Pisa ${ }^{75}$. Compañías financieras que competían entre ellas por tener la máxima presencia en todas

\footnotetext{
${ }^{73}$ El profesor COLLANTES DE TERÁN refería lo siguiente: "Eșta interrogante me la planteo a partir de la constatación de cómo algunos de los arrendatarios de impuestos en Carmona Solamente obtuvieron beneficios económicos mínimos, por no decir irrisorios, debido al escaso valor de las rentas que arrendaban o en cuyas subastas participaban" El sistema de arriendo de las rentas concejiles en las ciudades andaluzas, op. cit. p. 192. Para que este tipo de arrendamientos cobre algún sentido y hallemos una explicación, hay que relacionarlos con la cantidad de intereses que se formaban en torno a los arrendamientos, pues los arrendadores solían formar redes encabezadas por algunos financieros más poderosos. Conocemos casos en los que no solamente no había ganancias sino que hubieron perdidas constatadas. A pesar de ello el arrendador continuó arrendando la renta, prueba de que en dicho caso los beneficios eran de otra índole o estaban colocados en otro lugar. Nos estamos refiriendo concretamente al arrendador Francisco de Montalbán, que fue arrendador-recaudador mayor del partido de la Alcaicería de la ciudad de Granada los años 1495-1496 y 1496-1497. A. ORTEGA, La Fiscalidad Regia en el Obispado de Granada, op. cit.

${ }^{74}$ Deberíamos insistir en este tipo de fuente, pues son una verdadera "mina" de información.

${ }^{75}$ El término de compañía rival dẹbería ser matizado pues era muy común que los arrendadores -a pesar de tener compañías, o asociaciones bien definidas- colaborasen y actuasen conjuntamenmenos hasta el año 1491 . M.A. LADERO QUESADA,
Hacienda regia castellana, op. cit. pp. 429, 446, 503.
} 
las zonas de la Corona castellana, extendiendo su radio de acción en diferentes ámbitos geográficos.

Es en este creciente clima de oligopolios donde se desarrollan los principales fraudes y estrategias en las subastas de las rentas. Las primeras denuncias contra la compañía que había acaparado una gran parte de las rentas castellanas entre 1473 y $1494^{76}$ - la liderada por Rabí Mayr y Abraham Seneor-, tuvieron lugar en el año 1487 con un argumento acusador muy concreto: manipulaban a su antojo las pujas, pues hacían "çierta confederación e fabla para que otros çiertos arrendadores e personas no arrendasen nuestras rentas ni hablasen en las pujar, porque quedasen con ellos entera postura en que las avían puesto" 77 . A pesar de que la denuncia no prosperó, la misma inculpación volvió a recaer sobre sus protagonistas en los años 1490 y 1494: el fraude tornaba a gravitar sobre estos arrendadores ${ }^{78}$, con la diferencia de que está vez la acusación tuvo graves consecuencias para estos financieros.

Ante estas últimas imputaciones la respuesta no se hizo esperar y como legítima defensa inculparon a la compañía rival - aquella que llevaba años denunciándolos- no solamente de mentir sobre sus actuaciones y procedimientos, sino de ser ellos los que estafaban, defraudaban y manipulaban en el Estrado de las Rentas; y así se lo expresaron a los monarcas:

\begin{abstract}
E tanbien porque estando las rentas en nosotros siempre se pujan, lo que no se hase quando están en otros; e vídose por espirinçia quando las tobo Abraual que se pregonaron tres meses e nunca se halló quien hablase en ellas e luego como yo, por mandado de vuestras Altesas entendí en ellas, se pujaron en grand suma y paresçe la cabsa que aunque nosotros tengamos todo el Reyno no damos parte a ningún arrendador y es forçado que han de pujar lo qual no hasen otros ${ }^{79}$.
\end{abstract}

Más allá de los cruces de acusaciones y de los pleitos, que ponían de manifiesto las rivalidades entre las diferentes compañías por ejercer su oligopolio, estas denuncias nos revelan que los grandes arrendadores y las principales asociaciones, solían controlar las subastas utilizando prácticas fraudulentas. Fernán Núñez Coronel (el antes llamado Rabí Mayr) acusó a Alonso Gutiérrez de Madrid de negociar las pujas a cambio de compartir el negocio de las rentas con muchos de los que estaban dispuestos a pujar: “(...) que después de esta puja hecha por Alonso Gutierres se hallará aver rogado a muchos que tomen parte con él y algunos la han tomado" ${ }^{80}$, mas si Fernán Núñez Coronel acusaba a Alonso Gutiérrez de Madrid, es porque este último

\footnotetext{
${ }^{76}$ Para conocer más datos sobre esta compañía vid. nota 3.

${ }^{77}$ C. Álvarez, Los judios y la hacienda Real, op. cit. p. 99; M. A.LADERO, La receptoría y pagaduría general de la Hacienda regia castellana, op. cit. p. 430.

${ }^{78}$ En 1490 se pidió que se diese por nula la postura de Rabí Mayr: "ser ninguna asy como fecha por dolo e fraude del dicho Rabi Mayr, o a lo menos contener en sí fraude o decebción en gran suma e diminuçión de vuestras rentas" M.A. LADERO, La receptoría y pagaduría general de la Hacienda regia castellana, op. cit. p. 431.

${ }^{79}$ C. Álvarez, Los judios y la hacienda Real, op. cit., Anexo IV, p. 122.

${ }^{80}$ Ibíd. p. 124.
} 
intentaba arrebatarle las rentas, pues dicha estrategia había sido utilizada por él mismo años atrás. En el año 1492 este pidió a su hermano, Luis Núñez Coronel, que no pujase en ciertos partidos, pues él tenía la intención de quedarse con todos. A cambio de su aceptación, le prometió cederleposteriormente- parte de las rentas que él arrendara, bien directamente bien concediéndole la gestión de ellas ${ }^{81}$.

Estas compañías no fueron las únicas que se vieron envueltas en este tipo de inculpaciones, pues importantes agentes del fisco - como Pedro de Santa $\mathrm{Cruz}^{82}$ - también tuvieron que enfrentarse a ellas. En 1499 se presentó una querella judicial contra este conocido arrendador arandino, en la que se le acusaba de haber cometido muchos fraudes en la recaudación de las rentas: concretamente de hacer extorsiones para evitar que algunas personas pujasen al producirse la subasta ${ }^{83}$.

No siempre tenemos la suerte de contar con estos preciosos pleitos y testimonios, que nos ofrecen una documentación muy rica y detallada sobre las prácticas desarrolladas por los pujadores en el Estrado de las Rentas. De hecho son muy escasos los que conocemos si los ponemos en relación con la gran cantidad de corruptelas que debían acometerse asiduamente en las diferentes rentas castellanas. Destaparlas supone una labor compleja que requiere del análisis pormenorizado de los procesos de subasta y remates de las rentas. Escaparía a nuestras pretensiones presentar aquí un listado exhaustivo de todas ellas, pero a modo de ejemplo reflejaremos algunas que nos permitan inferir lo que se escondía tras cada remate.

Entre los años 1497-1500 Alonso de Alanís consiguió ser nombrado repartidor general de la renta de la seda del Reino de Granada, encargándose - tal y como correspondía a dicho nombramiento- de supervisar todas las subastas relacionadas con este producto ${ }^{84}$.

El repartidor sevillano no solamente desempeñó las tareas propias de su oficio, sino que aprovechó su lugar, cargo y posición para manipular en su propio beneficio las almonedas de una de las rentas más importantes del Reino. El análisis pormenorizado de los personajes que actuaron en las subastas y los resultados finales de éstas, así lo confirman:

1)Las subastas que a priori se esperaban muy animadas - pues estamos ante una de las rentas más importantes del Reino- transcurrieron con una escasa presencia de licitadores.

\footnotetext{
${ }^{81}$ Ibid. p. 109

${ }^{82}$ Entre muchas de las rentas que arrendó, fue arrendador mayor en la Merindad de Santo Domingo de Șilos durante quince años. Sobre este personaje -que también trabajaba conjuntamente con financieros de la talla de Alonso Gutiérrez de Madrid, Pedro del Alcazar, o los Coronelvid. M. DIAGO HERNANDO, Arrendadores arandinos al servicio de los Reyes Católicos, op. cit, pp. 73-79 y 82-86. Para sus relaciones con otros grandes financieros J.M. CARRETERO, Los arrendadores de la Hacienda de Castilla, op. cit, pp. 161-163.

${ }^{83}$ M. Diago Hernando, Arrendadores arandinos al servicio de los Reyes Católicos, op. cit., pp. 75-76.

${ }^{84}$ Aquí solamente expondremos las conclusiones. Esta subasta fue analizada con detalle en A. ORTEGA, Arrendadores y recaudadores en el Obispado de Granada bajo el reinado de los Reyes Católicos, op. cit.; La Fiscalidad Regia en el Obispado de Granada, op. cit.
} 
2)Las pujas solamente lograron aumentar en trescientos mil maravedíes el precio de salida, cuando años antes - momento en el que la seda aún no había sido sometida a la reforma que la convertiría en la renta más cuantiosa del Reino ${ }^{85}$ - su precio logró ser aumentado en setecientos mil maravedíes.

3)La mayoría de los casos en los que existieron pujas, éstas se limitaron a ser muy escasas y a estar cubiertas por arrendadores próximos al repartidor general, pues si comparamos las pujas que fueron efectuadas por los socios de Alonso de Alanís, con las que realizaron los licitadores que acudían de manera libre a las subastas, podremos comprobar las diferencias entre unas y otras: las primeras se limitaban a cubrir el proceso y las segundas debían efectuar fuertes pujas, pues la competencia era dura y difícil.

El resultado final de las diversas pujas en el Estrado de las Rentas fue el siguiente: de los quince partidos que se subastaron once fueron adscritos directamente a Alonso de Alanís, sin que mediara ninguna puja por medio, no siendo casualidad que se encontrara entre ellos seda tan valiosa como la de las Alpujarras o la de la ciudad de Málaga ${ }^{86}$. Los otros cuatro partidos se adjudicaron -teóricamente- al mejor postor, mas el precio alcanzado y los personajes en los que finalmente se remataron las rentas, nos confirman que dicha subasta estaba pactada y manejada por el repartidor general. Exceptuando un partido, el resto se remató en manos de socios, amigos, familiares o fiadores del propio repartidor.

Un caso similar fue estudiado por el profesor Carretero Zamora, que analizó algunas subastas realizadas por el conocido arrendador y repartidor general Pedro del Alcazar, en el que los procedimientos, las prácticas y los resultados finales, son muy similares al que acabamos de exponer ${ }^{87}$.

Otros mecanismos tildados de ilegítimos hemos podido localizar en algunas de las subastas analizadas por nosotros, de los que pasamos a ofrecer algunas pinceladas a modo de ejemplo.

En el año 1495 Mahoma Abduladín y Nicolás López de Spindola, lograban convencer a Miçer López de Spindola de que renunciara a la parte que él poseía como arrendador de la seda del Reino de Granada, en favor de

\footnotetext{
${ }^{85}$ Sobre dicha reforma vid. Ana María Vera DELgADo, El levantamiento mudéjar y su incidencia en la percepción de los tributos de la seda. "Actas del III Simposio Internacional de Mudejarismo", Teruel, 1986 ,pp. 145-152; J. E. LOPEZZ DE COCA CASTAÑER La seda en el Reino de Granada (siglos XIII-XVI), en España y Portugal en las rutas de la seda. Diez siglos de producción y comercio entre Oriente y Occidente, Barcelona, 1996, pp. 33-57. A. ORTEGA, La Fiscalidad Regia en el Obispado de Granada, op. cit.

${ }^{86} \mathrm{En}$ el año 1495 , y sin que se hubiese producido aún la reforma, la seda de la ciudad de Málaga se remató en 683.000 maravedíes, la de Almería en 660.000 y la de Baza 540.000, frente a los 600.000, 400.000 y 421.000 que alcanzaron respectivamente en el año 1497. A. ORTEGA, Arrendadores y recaudadores en el Obispado de Granada bajo el reinado de los Reyes Católicos, op. cit. 163.

${ }^{87}$ J.M. CARRETERo ZAMORA, Los arrendadores de la Hacienda de Castilla, op. cit., pp. 154-
} 
ellos dos. A cambio lo nombrarían fiador de la renta, con los beneficios que dicho cargo conllevaba ${ }^{88}$.

Un año más tarde estos dos arrendadores - nuevamente de forma conjunta - intentaron arrendar las Rentas Mayores de la ciudad de Granada, partido del que habían sido arrendadores mayores en el año 1495, y con el que lograron obtener pingües beneficios. Una puja de cuarto les arrebató en el último momento la titularidad pero no la participación: pues lograron que el arrendador eliminara a algunos de los fiadores que había presentado en la relación inicial, y que los incluyera a ellos dos. Naturalmente alguna contraprestación debieron ofrecerle para que el arrendador accediera a sus peticiones.

\section{LA CONNIVENCIA DE LA CORONA}

E que por los recabdamientos de los maravedíes de las dichas nuestras rentas de cada un año no hayan de llevar ni lleven salario alguno pues que las rentas se arriendan juntamente con los recabdamientos dellas syn salario alguno excepto en el partido de Xeres que ha de tener el recabdamiento del Don Abrahen Seneor e en los partidos del serviçio e montadgo e de Plasençia e su tierra, de que nos hicimos merced a Yuçaf Abravanel, los quales dichos (...) queremos que gosen de las dichas mercedes para en toda su vida ${ }^{89}$.

Ante arrendamientos de esta magnitud, financieros de tal renombre y compañías tan consolidadas, la Corona y sus oficiales no podían permanecer al margen. No solamente las acusaciones directas sino otro tipo de indicios, como los que hemos analizado en el apartado anterior, revelaban que el sistema de arrendamientos en Castilla se caracterizaba por las irregularidades que año tras año acometían los agentes fiscales.

Que la Corona era conocedora de ello es algo evidente, pues los cuadernos de legislación hacendística así lo reflejaban. No obstante, una cosa eran las leyes redactadas y dictadas para todos los vasallos del Reino con la finalidad de sistematizar, regularizar y normalizar un sistema de recaudación, y otra eran los intereses particulares que la Corona podía tener en determinados momentos con ciertos grupos financieros. La Corona participaba en un doble juego que basculaba entre el cumplimiento de la legalidad vigente y la tolerancia de ciertas prácticas ilegales.

Evidentemente, las tácticas que urdían los financieros para hacer del arrendamiento un auténtico negocio perjudicaban principalmente a la

\footnotetext{
${ }^{88} \mathrm{Tal}$ y como se refleja en una carta de poder que alude a los beneficios de los fiadores: "Yaya el Nayar e Don Alonso Venegas vezinos de esta çibdad de Granada nos encomendamos a vuestra señoria e merced a la qual notificamos que el año pasado de noventa e seys nosotros dimos nuestro poder complido a Alonso de Alanys vesino de Sevilla (...) el qual dicho poder le dimos porque con el teniamos çierta parte en la dicha renta" AGS, EM̈R-I- leg. 9. f. 355r. La cursiva es nuestra.

${ }^{89}$ M.A. LADERO, Legislación hacendística, op. cit. cuaderno de alcabalas de 1491, disposición 38, p. 132. La cursiva es nuestra.
} 
Hacienda, pues los beneficios de aquellos rara vez eran compatibles con los de ésta. Sin embargo, y en momentos determinados, los monarcas favorecían con un trato especial a ciertos personajes y compañías financieras, si así lo requerían las necesidades del momento, aunándose en dicho caso los intereses de ambas.

La decisión regia de apoyar firmemente a unas cuantas compañías y arrendadores, otorgándoles algunos beneficios y permitiéndoles incumplir la normativa vigente, solía deberse a varios factores: 1) La Corona dependía económicamente de algunos de estos grupos de financieros. 2) Necesitaba disponer de liquidez o asegurarse la colocación de un gran número de rentas.

1) La gran mayoría de las imputaciones realizadas en contra de los grandes financieros fueron o bien desestimadas por la Corona o resultaron favorables a los acusados. Que estos cometían anomalías en el proceso de arrendamiento con el fin de enriquecerse era algo "público y notorio", sin embargo, la monarquía no estimaba oportuno mediar en el asunto, y cuando lo hacía era para restituir la buena fama y el buen hacer de sus financieros ${ }^{90}$. Tras las diversas acusaciones y querellas no se observa cambio alguno en el panorama, pues los mismos financieros siguieron arrendando las rentas e incluso ampliando -más si cabe- su radio de acción ${ }^{91}$.

Si tenemos en cuenta que las irregularidades no partían únicamente de estos hombres de negocios sino también de la propia Corona, entenderemos porque año tras año las mismas compañías y los mismos arrendadores acaparaban una importantísima fracción de las rentas castellanas, sin que existiese posibilidad de alternativa. A pesar de que los Reyes Católicos procuraron dotar a las subastas de las rentas del dinamismo y la competitividad de la que habían carecido en reinados anteriores, al intentar acabar con la práctica tan común de arrendar las alcabalas y tercias globalmente a una sola compañía" ${ }^{92}$ pues ellos "tenían poder y facultad para hacer de sus rentas lo que quisiesen y fuese a su serviçio" ${ }^{93}$, no pudieron evitar fomentar el oligopolio.

Que en el cuaderno de alcabalas del año 1484 se redactara un capítulo excepcional dedicado con exclusividad a Abraham Seneor y a Yuçaf Abravanel era una prueba más que evidente. No solamente se les concedía de por vida un salario por desempeñar las labores de arrendadores en los partidos

${ }^{90}$ C. Álvarez, Los judíos y la hacienda Real, op. cit. p. 100; M.A. LADERO, La receptoría y pagaduría general de la Hacienda regia castellana, op. cit. p. 430.

${ }^{91}$ Algo que se observa perfectamente en Pedro de Santa Cruz, M. DIAGo Hernando, Arrendadores arandinos al servicio de los Reyes Católicos, op. cit., p. 75 y en la compañía liderada por Rabí Mayr y Abraham Seneor M.A. LADERO, La receptoría y pagaduría general de la Hacienda regia castellana, op. cit. pp. 429-432.

${ }^{92} \mathrm{Algo}$ que llevaron a cabo Juan II y Enrique IV y que fue duramente criticado en las Cortes de 1451. Era conocido como el arrendamiento de la masa. M.A. LADERO, La Hacienda Real de Castilla op. cit. p. 26. "Alberto GARCIA UCLECIA, El papel de corredores y escribanos en el cobro de las alcabalas, "Historia, instituciones, documentos" 13 (1986), pp. 91-92. Una muestra de cómo se arrendaban las rentas en masa en dichos reinados en Amparo MARTíNEZ RUÍZ La Hacienda Real en Galicia en tiempos de Juan II, "En la España Medieval”, 31 (2008), pp. 439442 .

${ }^{93}$ AGS, Registro General del Sello (RGS) 1488-II, f. 161r. 
de Jerez y Plasencia - especificándose claramente que se trataba de una excepción $^{64}$ - sino que se incluía en un cuaderno de alcabalas generalizado para toda la Corona y no en unas condiciones de arrendamiento específicas para un partido o renta determinado. Los monarcas estaban haciendo público su compromiso con estos agentes del fisco.

La gran acaparación de rentas que logró esta compañía, manteniéndose durante más de una década como la compañía líder en el negocio de las rentas castellanas, hay que relacionarla con las relevantes operaciones de crédito realizadas por sus integrantes entre 1483 y 1487 a favor de los monarcas ${ }^{95}$, y por la dirección de la receptoría-pagaduría de los años 1491$1494^{96}$. A cambio de estos servicios, los monarcas les otorgaban todo tipo de facilidades, para convertirse en arrendadores-recaudadores mayores de casi todas las rentas que desearan. Facilidades que pasaban por permitir que incumpliesen los procedimientos regulados para licitar en el Estrado de las Rentas: "Que sy es nesçesario e nos las avemos por rematadas aunque no le pregonen según lo mandan las leyes del nuestro cuaderno" $"$.

A partir del año 1494 los monarcas decidieron traspasar todos los privilegios detentados hasta el momento por la compañía de Fernán Núñez Coronel, a la compañía de Alonso Gutiérrez de Madrid y Fernando de Villarreal. La muerte de Fernán Pérez Coronel (Abrahem Seneor), el fracaso de la receptoria pagaduría general, y las denuncias de fraude que pesaban sobre la compañía, fueron elementos determinantes para que la Corona reemplazase a la que hasta la fecha había sido la principal compañía financiera en el reinado de los Reyes Católicos. A partir de ese momento, esta compañía gozaría de privilegios muy similares de los que había disfrutado hasta la fecha Fernán Núñez Coronel: permisividad para monopolizar las subastas y ausencia casi total de fianzas.

Que este tipo de condiciones eran completamente ilegales y estaban prohibidas por la legislación, era algo de lo que eran conocedores los propios arrendadores que las disfrutaban, pues en el momento en el que dejaban de gozar del favor regio así lo expresaban. La frase no puede ser más esclarecedora si tenemos en cuenta que es emitida por Fernán Núñez Coronel refiriéndose a Alonso Gutiérrez de Madrid: “y, sy esto yo hisiese, sería fraude e hasiéndolo él, hase servicio" 98 . Aquel ya no pertenecía para los reyes a lo más granado de la elite financiera, pasaba a ser uno más de la gran masa de financieros que operaban en Castilla y como tal era tratado y juzgado.

\footnotetext{
${ }^{94}$ M.A. LADERO, Legislación hacendística, op. cit. cuaderno de 1484, disposición 39, y cuaderno de 1491 donde vuelve a aparecer reflejado en la disposición 38. Respectivamente pp. 213 y 132 .

${ }^{95}$ M.A. SOLINís, La Alcabala del Rey (1474-1504), op. cit. p. 361.

${ }^{96} \mathrm{M}$. A LADERO, La receptoría y pagaduría general de la Hacienda regia castellana, op. cit. pp. 427-439.

${ }^{97} \mathrm{AGS}$, EMR, leg. 41, f. 13r. Frase emitida por la Corona.

${ }^{98}$ C. Álvarez, Los judios y la hacienda Real, op. cit., Anexo IV, p. 124.
} 
En algunas ocasiones la dependencia, el pago, o el pacto al que se había llegado con algunas de estas compañías, obligaban a los monarcas a tener que rechazar ofertas muy atractivas, tal y como ocurrió con las rentas de las Alpujarras ${ }^{99}$. Para el año fiscal de 1494-1495, los alguaciles moros de las Alpujarras ofrecieron una muy buena oferta para ser nombrados arrendadores-recaudadores mayores de las rentas de dicho lugar. A pesar de las opiniones de dos de los mejores conocedores de la fiscalidad granadina - Hernando de Zafra y Fray Hernando de Talavera- Isabel y Fernando decidieron adjudicarle la renta a la compañía de Alonso Gutiérrez de Madrid. Aunque tal y como expresara el Arzobispo de Granada con dicho arrendamiento "pareçe que antes se pierden dineros que se ganan ${ }^{100 ", ~ o ~ e l ~ p r o p i o ~}$ Hernando de Zafra "pareçiome que por ella antes vuestras altesas erán deseruidos que no seruidos ${ }^{101}$ ", los monarcas aceptaron un arrendamiento nada beneficioso para ellos y al que Alonso Gutiérrez de Madrid y sus socios pudieron acceder sin necesidad de entregar fianzas: “(...) Syn que den otras fianças ny abonos ny otra seguridad alguna" ${ }^{102}$.

2) El peso de las rentas más importantes y sustanciosas de la Corona no solamente recaía en las grandes compañías de arrendadores, sino también en importantes figuras que prestaban un valioso servicio a la Hacienda: nos estamos refiriendo a los repartidores generales. Se trataba de un arrendador que arrendaba en masa una gran cantidad de rentas, que posteriormente serían subarrendadas por él, figura -que lógicamente guardando las diferenciasrecuerda a los grandes maseros de época de Juan II y Enrique IV. La Corona simplificaba a través de este personaje las operaciones de subasta, a la vez que adquiría una seguridad rápida sobre la totalidad de las rentas que se adjudicaban a dicho repartidor. ¿Eran dichos elementos suficientes para que la Corona diese rienda suelta a dichos repartidores, permitiéndoles actuar en todo el proceso de subarrendamiento a su libre albedrío? ¿Se consideraban los monarcas más que servidos, colocando en un segundo plano no ya la legalidad sino la cuantía en la que se podían acabar rematando cada una de estas rentas? ¿Estaban pagando estos servicios, e incluso otros que desconocemos, permitiéndoles arrendar rentas muy sustanciosas a precios muy bajos? Evidentemente sí: el arriendo de impuestos era utilizado por los monarcas para devolver ciertos préstamos o como pago de ciertos servicios. A cambio estos personajes utilizaban el Estrado de las Rentas para su propio beneficio y el de sus compañeros de negocios.

\footnotetext{
${ }^{99}$ En el Obispado de Granada.

${ }^{100}$ SALVA Y SÁINZ DE BARANDA (1846-1895), Colección de Documentos Inéditos para la Historia de España, (CODOIN), XI, Madrid, 1846-1895, p. 520; Juan DE LA OBRA SIERRA, La Correspondencia de Hernando de Zafra (en prensa), Granada, registro 34 (Agradecemos a su autor que nos facilitara una copia del trabajo aún inédito).

${ }^{101}$ CODOIN, XI, p. 555; J. DE LA OBRA SIERRA, La Correspondencia de Hernando de Zafra op, cit., registro 51

${ }^{102}$ AGS, EMR-I- leg.11, f. 315r.
} 


\section{A MODO DE CONCLUSIÓN}

Tal y como comentábamos al principio, nuestro propósito no ha sido otro que el de aproximarnos al negocio fiscal del arrendamiento de rentas regias en la Castilla de finales del S. XV. Conscientes de la complejidad del fenómeno, decidimos hacerlo desde un ángulo de visión limitado y concreto que era - a nuestro entender - el punto de partida de dicho negocio. Este no podía entenderse, y ni siquiera emprenderse, sin que previamente se hubiesen adjudicado los arrendamientos, por ello se hacía imprescindible un estudio sobre los mecanismos que los posibilitaban.

Aunque como ya dijera en su día Jean Favier para que el sistema de arrendamientos funcionase debían coexistir los intereses de los poderes públicos con los de los arrendadores ${ }^{103}$, ambos intereses no siempre eran compatibles - tal y como hemos podido observar-. A pesar de que unos y otros formaban parte del mismo juego y de que aunaban sus fuerzas para evitar fraudes en el pago de tributos como las alcabalas, - pues esto sí beneficiaba a las dos partes - los arrendadores no eran oficiales públicos sino hombres de negocios, y por ello, en muchas ocasiones, sus intereses particulares primaban sobre los de la Hacienda.

Aunque el negocio y el fraude eran dos elementos que no necesariamente debían ir unidos, algunos de los materiales que hemos presentado y analizado aquí nos han revelado una cuestión muy clara: sin fraude podía haber negocio aunque no tan sustancioso. Para obtener pingües beneficios había que controlar al detalle el proceso de arrendamiento, algo que se lograba desarrollando diversas prácticas fraudulentas en el Estrado de las Rentas.

La legislación hacendística castellana, sobre todo la redactada bajo el reinado de los Reyes Católicos, fue uno de los medios de acción más importantes con los que contó la monarquía hispánica para luchar contra el fraude. Más de un siglo de experiencia arrendando rentas como las alcabalas, posibilitaron que cuadernos como los de 1484 y sobre todo 1491, registrasen una gran cantidad de actuaciones fraudulentas perfectamente localizadas, detalladas y sancionadas, que unidas al rigor con el que gobernaron los Reyes Católicos su Hacienda, daba como resultado que tanto las rentas como sus gestores se encontraran más fiscalizados que nunca. Aunque dicha fiscalización no era sinónimo de constricción, pues fueron Fernando e Isabel los primeros monarcas que conscientes de las posibilidades de su Hacienda -y del control que podían ejercer sobre ella- facilitaron y flexibilizaron el acceso a las subastas de las rentas: la sistematización de las pujas de cuarto o la libertad para ganar prometidos, fueron algunas de las medidas tomadas por ellos para dinamizar el Estrado de las Rentas. Evidentemente a mayor dinamización, mayor participación y más posibilidad de fraude.

${ }^{103}$ J. FAVIER, Finances et fiscalité, op. cit. pp. 227-228. 
A través de algunos de los ejemplos que hemos desarrollado aquí, hemos querido mostrar que el sistema de subastas - y por tanto la adjudicación de las rentas - no se regía por un procedimiento de pujas al alza que estaba perfectamente regulado, sino por una cantidad de vínculos y estrategias de los que participaban los financieros y la propia Corona.

Casi con toda probabilidad, muchos de los arrendadores e importantes compañías que dominaron la casi totalidad de rentas castellanas durante un largo periodo de tiempo, o que se hicieron dueños y señores de determinados partidos fiscales, no hubiesen cosechado tales éxitos sin la ayuda de los monarcas. Los reyes necesitaban asegurarse no solamente su financiación, sino también que sus rentas eran gestionadas por experimentados financieros. Para ello favorecían a determinados agentes particulares, que se caracterizaban por poseer una amplia capacidad crediticia, que siempre estaban dispuestos a colocar al servicio de la Corona. Es un esquema perfectamente comprensible - a mayor beneficio de estos agentes mayor seguridad para los reyes- que nos permite plantear algunas conclusiones provisionales.

Los Reyes Católicos quisieron hacer una clara distinción entre su reinado y el de sus predecesores, fomentando la limpieza, la transparencia y la igualdad de oportunidades en los arrendamientos de sus rentas. Los arrendamientos de la masa dejaron de utilizarse y nuevos mecanismos se emplearon para avivar la participación en las subastas. Sin embargo, este reinado tuvo una activa política exterior - con el consiguiente aumento de los gastos- que se traducirá en una necesidad cada vez mayor de recurrir a los préstamos. Los monarcas se debatían en una doble realidad, pues equilibrar ambos elementos resultaba muy complicado. Los reyes tuvieron que utilizar un doble rasero a la hora de tratar a los financieros y a la hora de luchar contra el fraude, pues prácticas tan escandalosas, y tan denunciadas, como la de adjudicar rentas sin pregones y sin subasta, fueron admitidas por la Corona. Ya no es que el juego no fuera limpio y transparente por parte de los licitadores, sino que finalmente acababa siendo la mano de la Corona la que decidía quiénes se convertirían en sus arrendadores. Teniendo en cuenta este elemento nos surgen algunas cuestiones, que aunque por el momento no estamos en condiciones de responder, nos gustaría dejar apuntadas. Sabemos que en lugares como el Obispado de Granada, recién conquistado e incorporado por los Reyes Católicos a la Corona castellana, el setenta y cinco por ciento de las rentas estaba controlado por importantes financieros judeoconversos $^{104}$. ¿Pudieron los Reyes Católicos trazar un plan consciente para tolerar la llegada de elementos que podían ser especialmente útiles en el nuevo Reino? ¿Pudieron llegar estas compañías y arrendadores al Obispado granadino de manos de los propios monarcas? ¿Hasta qué punto no estaba interesada la monarquía en potenciar estos grupos, cuando eran ellos los que aseguraban el abastecimiento tanto de productos como de capitales?

\footnotetext{
${ }^{104}$ A. ORTEGA, La Fiscalidad Regia en el Obispado de Granada, op. cit.
} 
Como vemos son todavía muchas las incógnitas que están sin despejar y muchos los intereses que se escondían en la cantidad de operaciones que se formaban en torno a cada arrendamiento. Sólo cabe esperar que nuevas investigaciones nos permitan terminar de descifrar un mundo todavía cubierto de demasiadas sombras.

Fecha de recepción del artículo: noviembre 2009.

Fecha de aceptación y versión final: marzo 2010. 
